\title{
Determinants of Capital Flight in the East African Community
}

\author{
Shem J. Otieno* $^{*} \quad$ Symon K. Kiprop Augustus S. Muluvi \\ Department of Economics, Egerton University \\ P.O Box 536, Egerton, Kenya \\ *Email: shemjoshuashem@gmail.com
}

\begin{abstract}
The region has lost an immense amount of capital that has led to sluggish regional integration in terms of capital formation and productive capabilities. Albeit most of these countries are in the ranking list of the huge volumes of capital flight, East Africa has never been considered as a sub-region in the capital-related studies. Cognizant of this, this paper intends to contribute to this body of knowledge by filling a noticeable gap. This paper examined the determinant of capital flight from East African Community countries that include Kenya, Tanzania, Uganda, Rwanda, and Burundi using panel data for the years 1988 to 2018 using the real gross domestic product, interest rate differential, external debt, corruption index, and exchange rate as explanatory variables. Secondary data obtained from EAC member countries National Bureau of Statistics. Levin-Lin-Chu panel unit root test was carried out and capital flight and Exchange rate found to be stationary at level. The fixed effect regression results showed that corruption, external debt, and the exchange rate had a positive and statistically significant effect on capital flight while real GDP had a negative and statistically significant effect on capital flight. Thus, policymakers should endeavor to achieve a broad investor base for its domestic and foreign obligations, with due regard to cost and risk, and should treat investors equally. In addition, there is a need to harmonize the judiciary and the executives in EAC to facilitate the fight against corruption which is a major concern for a capital flight.
\end{abstract}

Keywords: Capital flight, External debt, Exchange rate, GDP, Corruption, EAC

DOI: $10.7176 / \mathrm{JESD} / 12-10-01$

Publication date:May $31^{\text {st }} 2021$

\section{Introduction}

After the 1990s, Sub-Sahara African countries prescribed to liberalize their capital accounts and followed a number of standard policy solutions in order to attract foreign capital inflows to finance investment as well as their rising debt stocks (Forson et al., 2017). However, capital flows take place in the opposite direction as the residents of these countries move the already scarce capital to more advanced economies. According to World Bank (2017), capital flight has led to disappearance of capital for domestic investment in Sub-Sahara Africa, thus leading to a fall in the rate of capital formation that is important in promoting economic growth and development. In addition, due to capital flight, Sub-Sahara Africa has continued to lag behind in terms of physical and human capital investment thus leading to a decline in economic growth and development (Ndikumana \& Boyce, 2012).

Given the investment-growth nexus, capital flight has contributed to the sluggish growth in affected economies through reduction in government tax revenue and its debt servicing capacity since income earned abroad cannot be taxed. According to World Bank Annual General Meeting Report (2005), consequences of capital flight in Sub-Sahara Africa includes the over reliance on a few exports due to the under development of the manufacturing sectors, high vulnerability to terms of trade shocks and a narrowed taxation. Basically, Africa continent is prone to over-borrowing from developed economies to finance major governmental and private projects.

During post 1980s, several African countries experienced overwhelming currency instability and changes in exchange rate regimes. It was at the same time that significant levels of capital flight from Sub-Saharan Africa began developing. According to Ndikumana and Boyce (2012), exchange rate misalignment highlights the errors in macroeconomic policy, which presents a case for capital flight. Uncertainty arising from expected real currency depreciation and appreciation offers an interesting paradox for asset losses by economic agents. When agents anticipate a real depreciation, they tend to engage in capital flight to avoid the risk of loss of purchasing power. Even a real appreciation may trigger expectations of future depreciation. Shortage of liquidity due to upward pressure on interest rates reduces the capital formation in the country, and can adversely affect the country's current and future economic conditions (Makochekanwa, 2007).

\subsection{Trends of Capital Flight in EAC}

The magnitude of East Africa Community Member States' capital flight is staggering both in absolute monetary values and in relative GDP. According to Ndikumana and Sarr(2016), on average, EAC lost US \$23.28 billion between 1988 to 2015 alone. However, if this capital would have been invested locally in income earning infrustructuresduring that period, it would have aided to minimize the debt burden since the region would have accummulated significant amount of capital to help in serving its economic development projects. This is 
becauseretention of capital helps to improve usage of available resources to finance the needed infrastructures which has been lagging behind in terms of economic development and growth in EAC. From Table 1, the EAC members have lost a considerate amount of capital through capital flight which has led to economic sluggish growth in the region over the last 30 years.

Table 1: Capital flight from EAC between 1988 and 2018 as a percentage of the real GDP

\begin{tabular}{|c|c|c|c|c|c|c|c|c|c|c|c|c|c|c|c|c|}
\hline 常 & $\begin{array}{l}\infty \\
\stackrel{8}{\circ}\end{array}$ & ఏ & § & ڤั & ஃั & $\stackrel{\infty}{\circ}$ & $\S_{\bar{A}}$ & 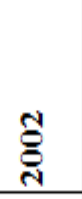 & 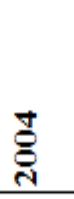 & $\oiint_{4}$ & $\stackrel{\infty}{\stackrel{2}{*}}$ & $\stackrel{g}{\vec{n}}$ & $\stackrel{N}{3}$ & $\underset{\pi}{\Delta}$ & $\stackrel{\infty}{\vec{N}}$ & $\stackrel{\infty}{\vec{\pi}}$ \\
\hline Kenya & 0.2 & 4.9 & 2.8 & 2.1 & 4.9 & 5.3 & 1.5 & 3.6 & 10.9 & 1.3 & 1.4 & 0.7 & 4.1 & 6.2 & 4.8 & 4.0 \\
\hline Tanzania & 6.3 & 0.4 & 0.4 & 1.2 & 2.0 & 2.0 & 1.9 & 1.7 & 4.4 & 21.4 & 1.7 & 5.3 & 13.0 & 7.4 & 6.6 & 6.2 \\
\hline Uganda & 3.1 & 7.9 & 3.9 & 4.1 & 0.2 & 0.3 & 4.2 & 6.8 & 8.2 & 18.0 & 10.5 & 5.9 & 3.7 & 2.8 & 3.1 & 3.0 \\
\hline Rwanda & 6.6 & 4.8 & 0.4 & 10.5 & 0.5 & 2.3 & 2.1 & 1.1 & 8.0 & 21.6 & 5.2 & 3.6 & 20.9 & 7.0 & 6.2 & 5.4 \\
\hline Burundi & 8.4 & 11.3 & 13.0 & 4.3 & 6.8 & 13.5 & 10.4 & 17.0 & 8.0 & 27.2 & 4.8 & 1.8 & 4.6 & 10.9 & 9.8 & 10.8 \\
\hline
\end{tabular}

Source: World Bank's Global Development Indicators Database (2018)

From Table 1, in 1988, Kenya experienced a stable economic growth which was due to economic growth spillover on stable macroeconomic variables from 1986. This was as a result of the government emphasis on the economic management for renewed economic growth. Due to openness in debt management, there was a reduction in external debt that led to low capital flight of 0.2 percent as a percentage of GDP compared to preceding years(KNBS, 2017).Between the year 1990 to 1993, Kenya faced a foreign exchange crisis that resulted from withholding of the donor funds thus leading to low GDP growth and high inflation growth rate running at a double digit of 46 percent. As a result, the rate of capital flight grew and stood at 2.1 percent of the total national GDP by 1994 which was equivalent to US \$150.2 million of total GDP ( $\mathrm{Ng}$ 'eno, 2000). The rate of capital flight grew in 2004 to 10.9 percent, which was representing an absolute value of US $\$ 1.75$ billion due to increased corruption cases experienced in the previous years 2002 and 2003. For instance, the country faced a multi-billion shilling Anglo Leasing scandal leading a loss of approximately 6 percent of the total real GDP between 2002 to 2004 (Centre for Applied Research, 2015). In the year 2006 to 2010, the rate of capital flight declined from1.3 percent to 0.7 percent due the government Economic Recovery Strategy (ERS) which was a five year plan to correct the country's macroeconomic structural weaknesses (IMF, 2011). In order to service its infrastructural developments, external debt increased subsequently between 2012 and 2018. External debt generally created a condition for a capture, commonly known as loot to the elites thus lowered the saving rate of Kenya(World Bank Report, 2016). As a result, the capital flight rate increased from 4.1 percent to 6.8 percent, representing US \$2.07 billion to US $\$ 4.18$ billion in absolute value for the GDP. It then declined from 4.8 percent to 4.0 percent of the real GDP, which also represented US $\$ 3.32$ billion to US $\$ 3.5$ billion of the total GDP respectively from the year 2012 to 2018(World Bank's Global Development Indicators Database, 2018).

Tanzania's GDP per capita declined at levels lower than those registered during the first half of the 1980s. This was preceded by positive real net private transfers and short-term capital inflows between 1988 and 1994 . In 1988, the current account of Tanzania worsened due to fluctuation in macroeconomic factors that led to 6.3 percent of capital flight, which was equal to US \$321.3 million in absolute value of the total GDP(ICO, 2013). However, in 2006 , the country experienced the highest rate of capital flight of 21.4 percent which was motivated by foreign debts from developed economies given uncertainties about future repayment for the debts. Residents were therefore motivated to export their earnings for investments to foreign countries, majorly USA, UK and Jersey Island due to excessive borrowing owned by state to foreign nations (Nyoni, 2000). As a result, the IMF and the Word Bank provided the economy of Tanzania a debt relief in the year 2006 (Kar et al., 2010). Tanzania is considered to be among the Heavily Indebted Countries (HIPC) by the IMF thus it enjoyed debt relief initiative 
that promoted the capital formation in the year 2008. As a result, the capital flight maintained a low rate in the year 2008 and 2010 at 1.7 and 5.3 percent. Given the debt burden that the country has been facing, Tanzania citizens always try to avoid heavy taxes to finance heavy debts in future by transferring part of their earnings abroad to increase gains and capital interests (WB, 2017).

Uganda maintained stable economic growth from 1994 to early 2000 where it successfully removed various disincentives that helped it recover from economic crisis experienced in early 1988. From Table 1, the rate of capital flight declined to 0.2 percent of the total GDP in 1996 (US \$12.1 million), and then kept increasing in 1998 where it was 0.3 percent of the total GDP (US \$19.8 million), then to 4.2 percent in the year 2000 which was US $\$ 259.4$ million of GDP in absolute value. Increase in capital flight rate in 2000 was due to weak performance of the financial sectors and increased political instability. The persistent increase in capital flight was experienced through the year 2006 through 2008 when the country experienced corruption and unstable political events. It led to weak interest rate earning from the domestic and corporate earnings thus lowered rate of investment (Word Bank, 2017). Introduction of the monetary and fiscal policies helped to curb the increased rate of capital flight from 2010 to 2018. As a result, the rate of capital flight declined from 5.9 percent in the year 2010 to 3.7 percent in 2012 , then to 2.8 percent in 2014 . It then increased to 3.1 percent of the total GDP in 2016 before it declined again to 3.0 percent of the total real GDP which is US \$ 987.6 million in absolute value.

From Table 1, in 1988, the amount of capital flight from Rwanda amounted to 6.6 percent of the total GDP which represented US \$158.07 million. This was accompanied by high value of external debt that kept increasing as a result of low capital formation in 1988. Due to increased external debt in 2006, the country experienced an increased capital flight of 21.6 percent of the total national GDP (US \$717 million) which forced it to source for its infrastructural developments. However, the economy stabilized in 2008 to 2010 when it decided to reduce its debt burden through reduction in its expenditure and tightening the revenue collection systems (World Bank Report, 2017). As a result, there was low capital flight ranging from 5.2 to 3.6 percent of the total real GDP which represented US $\$ 166.3$ million on average. In 2012, external debt of Rwanda increased at a rate of $35 \%$ of the total GDP which led to a double digit capital flight percentage of 20.9 percent of the real GDP (US \$1.6 billion).

Regarded as one of the world poorest nations, Burundi is struggling to rebuild after a decade's long civil war that ended in 2006. Capital flight increased in the year 1990 to 1992 from 11.3 percent (US \$12.8 million) to 13.0 percent of the total GDP (US \$140.7 million) as a result of a negative economic growth that was caused by civil war. However, the IMF and the World Bank intervened in 1994 to provide non-interest paid loan to the government to service economic developments thus reduced the capital flight to 4.3 percent of the total national real GDP before it increased to 6.8 percent, which was equal to US \$59.1 million of the total GDP in 1996 (World Bank Report, 2008).After the civil war that ended in 2006, the national government implemented stabilized macroeconomic policies that helped to reduce the capital flight which reduced to 4.8 percent in 2008 (World Bank Report, 2008). Government through the central bank liberalized its currency implemented some governance system tools that prevented increased corruption by 2010. As a result, the capital flight rate reduced to 1.8 percent of the total real GDP which kept a figure below 5.0 percent up to 2014(World Bank, 2017). However, according to Ndoricimpa (2018), political instability and corruption that rocked the country in 2014 led to increased capital flight which was averagely above 10 percent of the total real GDP from the year 2014 to 2018 .

\subsection{Statement of the Problem}

For the past four decades, most EAC Member States' economic performance has been characterized by economic stagnation. This is because capital flight from EAC economies constitutes a serious development challenge for several reasons. First, in recent decades capital flight has been both sizable and costly relative to scare capital formation in EAC. The loss of scarce capital and foreign exchange potentially leads to a loss of investment in countries that are in great need of more infrastructure, plant and equipment, and human capital. Secondly, capital flight has a substantial regressive impact on wealth distribution in EAC since it is the members of the subcontinent's economic and political elites that take advantage of their privileged positions to engage in capital flight by acquiring and channeling funds abroad. The impact of the resulting shortages of revenue and foreign exchange is borne by the poorest members of society in the EAC member States. The regressive impact of capital flight is therefore compounded when financial imbalances result in devaluation: the wealthy that hold external assets are insulated from the effects, while the poor enjoy no such cushion. From the interaction, we can conclude that stable economic growth through domestic saving and investment promotes a favorable environment for the retention of capital flight. It is therefore on the ground of these findings that this study attempts to determine the factorsthat affectcapital flight in EAC Member states. Therefore this studyattempts

i. To investigate the determinants of Capital Flight in EAC

\section{Theoretical Literature Review}

Portfolio Adjustment theory, also known as portfolio choice theory was first developed by Markowitz in 1952. It states that investors seek to maximize profits by allocating their funds between domestic and foreign investment 
based on the relative risk- adjusted rates of return at home and abroad. The principal idea for the theory is that interest rate differentials is the main cause of capital flight from less developed countries to advanced economies. Following the logic of diminishing return, the rate of returns to capital should be higher in capital scarce developing countries than in capital- abundant developed countries, and capital should flow from the latter towards the former. If investment is riskier in developing countries, the net risk-adjusted returns may be lower and this could explain why capital continues to flow in opposite direction. Asset holders in the ordinary course of events engage in constant redeployment in search for an efficient portfolio, one that maximizes total returns under a given risk constraint (Liew, 2016). Capital flight can be viewed as a three-way trade off among secrecy, expected returns and risk.

While perfectly hidden transaction may be possible, the costs in foregone return and increased risk can be quite large. However, Markowitz' theoretical contributions to Portfolio Adjustment theory are built upon the assumption that investors are only willing to accept higher amounts of risk. This is only acceptable if investors are compensated by higher expected returns which are frequently contradicted by investor's contrary actions of capital flight from developing countries. Often, investment strategies demand that investors take on a perceived risky investment in order to reduce overall risk without any discernible increase in expected returns (McClure, 2010).

If investments in developing countries become risky, the risk adjusted returns become lower therefore, that will create an incentive for these investors to look for an area with higher rate of return with a lesser risk (Ndikumana and Boyce, 2011). Additionally, investors have certain utility functions that may outweigh distribution of returns concerns. This theory is well expounded in determining how interest rate differentials, Real GDP, and both non-economic risks influence the magnitude of Capital flight in an economy. To capture the other macroeconomic variables, the study looked on to the investment diversion theory which implicitly explained how real exchange rate affects the capital flight.

In summary, from the empirical studies reviewed, determinants of capital flight included real GDP, External debt, inflation rate, real exchange rate, growth differentials, and corruption. However, the studies were carried out long time ago with no study majoring on the EAC member states using panel data. At the same time, these studies did not cover post and pre capital liberalization from 1980s to millennium years. As a result, this study used real GDP, External debt, real exchange rate, real interest rate differentials, and corruption as the major macroeconomic variables using a panel data for the period of 1988 to 2018.

\section{Methodology}

The study used historical research design as it seeks to evaluate the determinants of Capital Flight in East Africa Community over the period 1988-2018. According to Buckley (2016), the main purpose of historical design is to collect, verify, and synthesize evidence from the past to establish the facts that tries to refute hypothesis. This research design was chosen because it enabled the researcher to capture the trend of capital flight of the member countries of EAC (Gisore, 2021).The study covered East African Community (EAC) comprising of five member states: Kenya, Uganda, Tanzania, Burundi and Rwanda and the time period was chosen based on the availability of data. The regional block was chosen since the countries have had a long history of budget deficit given that lots of capital flew from the region while their external debt almost equal to capital flight from the region.

\subsection{Empirical Model: Panel Data Estimation}

The study was guided by Portfolio Choice theory developed by Markowitz (1952) that explore reasons to why economic agents send their capital abroad to invest in a portfolio that maximizes the expected utility of their final wealth. The theory argues that capital flight will rise with increasing domestic economic and non-economic risks. The study used panel data regression analysis where by a linear regression analysis was used to estimate the relationship between capital flight and corruption index, external debt, real exchange rate, real GDP, and interest rate differential in EAC member States. This can be explained using the functional form;

$C F=C F(\beta 1, \beta 2, \beta 3, \beta 4, \beta 5, R G D P, I R D, I R D, C I, R E R)+\varepsilon$

The estimated model is given as;

$\operatorname{InC} F_{\mathrm{it}}=\beta 0+\beta 1 \operatorname{In} C I_{\mathrm{it}}+\beta 2 \operatorname{In} E D_{\mathrm{it}}+\beta 3 \operatorname{In} R E R_{\mathrm{it}}+\beta 4 \operatorname{In} R G D P_{\mathrm{it}}+\beta 5 \operatorname{In} \operatorname{IR} D_{\mathrm{it}}+\varepsilon_{\mathrm{it}}$

Where:

$\mathrm{CF}=$ Capital Flight,

$\mathrm{CI}=$ Corruption Index,

$\mathrm{ED}=$ External Debt,

RER $=$ Real Exchange Rate,

RGDP $=$ Real Gross Domestic Product,

IRD = Interest Rate Differential,

$\varepsilon_{\mathrm{it}}=$ Error term, $\beta_{0}=$ Intercept term, and $\beta_{1}, \beta_{2}, \beta_{3, \text { and }} \beta_{4}$ are slope coefficients.

Political instability and Forex fluctuations were used as control variables since they also influence rate of capital flight. 


\subsection{Panel Unit Root Test}

Panel Unit Root Testwas conducted to ensure that the variables are stationary and that none of them is of an order greater than I (I). Levin, Lin, and Chu (2002) unit test is superior test power for the long-run relationships in panel data analysis thanIm, Pesaran and Shin (2003) whichbegin by specifying a separate ADF regression for each crosssection with individual effects and no time trend.

$\Delta y_{i t}=\alpha_{i}+\rho_{i} y_{i, t ~}+\sum_{j=1}^{p_{i}} \beta_{i j} \Delta y_{i, t}+\varepsilon_{i t}$

Where $i=1, \ldots, N$ and $t=1, \ldots, T$

3.3 Co-integration Test

The study tested for the existence of a long-run cointegration among capital flight and the independent variables using panel cointegration tests suggested by Pedroni (1995). The procedures proposed by Pedroni make use of estimated residual from the hypothesized long-run regression of the following form:

$$
\mathrm{y}_{\mathrm{i}, \mathrm{t}}=\alpha_{\mathrm{i}}+\delta_{\mathrm{i}} \mathrm{t}+\beta_{1 \mathrm{i}} \mathrm{x}_{1 \mathrm{i}, \mathrm{t}}+\beta_{2 \mathrm{i}} \mathrm{x}_{2 \mathrm{i}, \mathrm{t}}+\ldots+\beta_{\mathrm{Mi}} \mathrm{x}_{\mathrm{Mi}, \mathrm{t}}+\mathrm{e}_{\mathrm{i}, \mathrm{t}}
$$

for $t=1, \ldots ., T ; i=1, \ldots, N ; m=1, \ldots ., M$,

Where;

$T$ is the number of observations over time,

$N$ number of cross-sectional units in the panel,

$M$ number of regressed variables

In this set up, $\alpha_{i}$ is the member specific intercept or fixed effects parameter which varies across individual crosssectional units. The same is true of the slope coefficients and member specific time effects $\delta_{\mathrm{i}} \mathrm{t}$.

\subsection{Hausman Test}

Panel data can be estimated by two techniques, fixed effect or random effect model. Therefore to establish whether to employ fixed effects model or random effects model, this study conducted Hausman test (1978) which tries to establish whether the error terms are correlated with the regressors, where null hypothesis states the absence of such correlation. One advantage of fixed effects model is that it allows the unobserved individual effects to be correlated with the included variables (Babu et al., 2014). In addition, lagging the dependent variable in a dynamic model may cause it to become correlated with the error term. This may lead to the problem of endogeneity of some explanatory variables. Therefore, tests for the mentioned problems were conducted before estimation which includes cross-sectional dependence, autocorrelation, and heteroscedasticity.

\section{Results and Discussion}

\subsection{Panel Unit Root Test}

Panel unit root test was conducted to find out whether the variables were stationary at level or whether they were non stationary at level and result reported in Table 2.

Table 2: Results of Levin-Lin-Chu Panel Unit Root Test

\begin{tabular}{|l|l|l|l|l|}
\hline Variable & LLC (level) & LLC(first difference) & LLC(p-value) & Order of integration \\
\hline LnCF & -2.2547 & & 0.0121 & $\mathrm{I}(0)$ \\
\hline \multirow{2}{*}{ LnCI } & -0.6670 & & 0.2524 & \\
\cline { 2 - 5 } & & -3.5681 & 0.0002 & $\mathrm{I}(1)$ \\
\hline \multirow{2}{*}{ LnED } & -0.0624 & & 0.4751 & \\
\cline { 2 - 5 } & & -3.9082 & 0.0000 & $\mathrm{I}(1)$ \\
\hline \multirow{2}{*}{ LnGR } & -4.3974 & & 0.0000 & $\mathrm{I}(0)$ \\
\hline LnIRD & 1.7188 & & 0.9572 & \\
\cline { 2 - 5 } & & -3.0643 & 0.0011 & $\mathrm{I}(1)$ \\
\hline
\end{tabular}

$5 \%$ significance level

From Table 2, capital flight, exchange rate and interest rate differential were found to be stationary at level while the remaining variables, that is corruption index, external debt and gross domestic product were found to be stationary after first differencing that is integrated of order one.

4.2 Cointegration Test

Usually after differencing, variables tend to lose long run relationship and so cointegration test is being conducted to establish whether variables have got long run relationship after differencing. The test's null hypothesis is that 
there is no cointegration while the alternative one is that all panels are cointegrated. Since some variables were found to be stationary at level and others stationary after first differencing, conducting cointegration test was impossible since the variables were now not integrated of the same order.

\subsection{Hausman Test}

To determine whether to use fixed effects or random effects regression model, Hausman (1978) test was conducted and the results were as follows:

Table 3: Results of Hausman Test

\begin{tabular}{lllll}
\hline -Coefficients- & (b) & (B) & (b-B) & Sqrt(diag(v_b- \\
& Random & Fixed & Difference & - \\
\hline LnCI & 0.2606429 & 0.6247703 & 0.3641274 & 0.1696555 \\
LnED & -0.3719954 & 0.3493321 & -0.0226634 & - \\
LnER & 1.721324 & 0.8475175 & 0.8708062 & 3.001903 \\
LnGDP & 0.6042411 & 0.8108851 & -0.206644 & \\
lnIRD & -1.685769 & -0.7321929 & -0.9535757 & \\
Chi2 $(4)=43.77$ & & & Prob $>$ chi2 $=0.0000$ & \\
\hline
\end{tabular}

From the Hausman test in Table 3 , the p-value is 0.0000 which is less than 0.05 which means that the difference is statistically significant and so the null hypothesis of the preferred model being random effects model was rejected. Thus, the fixed effects regression model was used to analyze the relationship between the dependent variable and the independent variables.

\subsection{Determinants of Capital Flight in EAC}

Table 4 presents the fixed effect regression results on the determinants of the capital flight in the EAC from 1988 to 2018 based on the panel data analysis.

Table 4: Results of Fixed Effects Regression

\begin{tabular}{|l|l|l|l|l|ll|}
\hline LnCF & Coef. & Std.Err. & $\mathrm{T}$ & $\mathrm{P}>|\mathrm{t}|$ & \multicolumn{2}{|c|}{ 95\% conf.Interval } \\
\hline LnCI & $0.6247703^{* *}$ & 0.4078072 & 1.53 & 0.018 & 0.5739142 & 0.6756264 \\
\hline LnED & $0.3493321^{* *}$ & 0.1723294 & 2.03 & 0.044 & 0.327841 & 0.3708226 \\
\hline LnER & $0.8475175^{* *}$ & 1.280379 & 0.66 & 0.029 & 0.6878463 & 1.0071887 \\
\hline $\ln$ GDP & $-0.8108851^{* * *}$ & 0.2325294 & -3.49 & 0.001 & -0.839883 & -0.7818872 \\
\hline $\operatorname{lnIRD}$ & $0.7321929 *$ & 2.091980 & 0.35 & 0.570 & 0.5719422 & 0.8924436 \\
\hline -cons & $-11.9538654 * *$ & 5.713972 & -2.09 & 0.038 & -12.6664331 & -11.2412977 \\
\hline R-sq: within & 0.5208 & \multicolumn{4}{|c|}{$\mathrm{F}(5,145)=11.32$} \\
\hline R-sq: Between & 0.8451 & Prob $>$ chi2 $=0.0000$ \\
\hline R-sq: Overall & 0.5434 &
\end{tabular}

$* * *$ is significance at $1 \% ; *$ is significance at $5 \%$ and $*$ is significance at $10 \%$

From the regression results, the coefficient of corruption index $(\mathrm{CI})$ is 0.6247703 . This means that a one percent increases in corruption leads to $0.6247703 \%$ increase in capital flight. Since the p-value of 0.018 is less than 0.05 , it means that the $0.6247703 \%$ increase in capital flight is statistically significant at $5 \%$ significance level. The coefficient is positive and this conforms to economic theory of portfolio adjustment postulated by Markowitz (1952) which emphasized that with riskier investment in developing economies due to non-economic indicators, there will be low return of investment locally thus escalating capital flight that flows to developed countries. This could be because corruption erodes the trust that people have in the public sector to act in their best interest. Corruption also wastes taxes or rates that have been earmarked for important projects and this translates to poor quality services or infrastructure which in turn promotes capital flight (Liew, 2016). Corruption also leads to minimal transparency on service to both citizens and investors which are sometimes discouraging hence contributing towards capital flight from a country. With corruption in existence in a country, honest businesses or investors ends up missing out on government contracts and this accelerates capital flight since the business environment becomes unconducive to investors (Osei-Assibey et al., 2018). The finding of this study found the coefficient of corruption index to be positive and statistically significant to capital flight thus conforms to the finding of Osei-Assibey et al. (2018).

From the fixed effects regression results, the coefficient of external debt (ED) is 0.3493321 . This means that a one percent increase in external debt leads to an increase in capital flight by $0.3493321 \%$. The p-value is 0.044 and being that it is less than 0.05 , it means that $0.3493321 \%$ increase in capital flight is statistically significant at $5 \%$ significant level. The coefficient is positive and conforms to debt-overhang theory which stipulates that the presence of inherited debt will be sufficiently large that creditors will not be able to have confidence in repayment. Thus, the finding of the study also conform to the debt-overhang theory since in any case the national debt exceeds the country's repayment ability, then the expected debt service will be likely to increase relative to national output 
(Kolapo et al., 2000). The results are in line to Ajayi (1997) and Babu et al. (2014)findings that postulated that increased external debt will result in increased taxation on national return in order to service the national debts thus discouraging both domestic and foreign investors.

The coefficient of exchange rate from the fixed effect regression results is 0.8475175 . This means that a one percent increase in exchange rate leads to a $0.8475175 \%$ increase in capital flight and p-value is 0.029 . This means that the $0.8475175 \%$ increase in capital flight is statistically significant as a result of a one percent increase in exchange rate being that the $\mathrm{p}$ value is less than 0.05 and the significance is at $5 \%$ level. The result is positive and conforms to economic theory of investment diversion theory postulated by Dunning and Robson (1988) which suggests that currency depreciation will bring about the fear of loss of asset value by the economic agents. This is because in the midst of expected currency depreciation, citizens would anticipate the economic agents to safeguard their assets by demanding higher valued currencies thus engaging in capital flight. The result relates to the findings of Bigsten et al. (1999), which empahasized that exchange rate overvaluation leads to high expectations of depreciation on domestic currency which in turn leads to an increase in the prices of foreign goods compared with prices of domestic goods hence resulting in losses in real incomes.

For the case of real gross domestic product, the coefficient is -0.8108851 which suggests that one percent increase in gross domestic product leads to a $0.8108851 \%$ decrease in capital flight. The p-value is 0.001 and being that it is less than 0.05 , it means that the decrease in capital flight by $0.8108851 \%$ as a result of a $1 \%$ increase in gross domestic product is statistically significant at $1 \%$ significance level. The result is negative and conforms to portfolio adjustment theory which emphasized that investors will only be willing to accept higher expected return which mostly contradicts the scenario in developing economies with low expected return (Liew, 2016). However, if GDP growth is stabilized, there will be higher chances of increased expected return in terms of capital gain and profit maximization from the investment. This is because a strong economic performance which is measured in terms of higher economic growth and stable institutions are associated with lower capital flight. A strong economic growth signals higher expected returns on domestic investment which induces further domestic investment and thus reduces capital flight. In addition, a high and sustained economic growth also gives confidence to domestic investors about the institutional and governance environment of the country which encourages domestic investment while reducing incentives for capital flight (Schneider, 2003). The result is consistent with the findings of Ndikumana and Sarr (2016)econometric analysis on the role of natural resource endowment on capital flight based on 32 African countries over the period 1970-2013.

The coefficient for the interest rate differential is 0.7321929 which means that an increase in interest rate differential by $1 \%$ leads to an increase in capital flight by $0.7321929 \%$. The p-value is 0.570 and being that it is greater than 0.05 , it means that the $0.7321929 \%$ increase in capital flight as a result of a $1 \%$ increase in interest rate differential is not statistically significant. According to Al-fayoumi et al. (2012), the higher the interest rate differential, the more attractive the foreign investments on assets which in turn induces net capital outflow. It also reduces expected returns on domestic investment thus encouraging domestic capital owners to send their capital abroad.

From the results in Table 4, the probability of F-statistics is 0.0000 which is less than 0.05 implying that the model is good fit and all explanatory variables are jointly statistically significant at 5 percent level of significance and adequate enough to explain change in capital flight. The within $\mathrm{R}$ squared is 0.5208 . This means that $52.08 \%$ of the variations on capital flight (dependent variable) within the individual countries are explained by the explanatory variables in the model. The between $\mathrm{R}$ squared is 0.8451 which means that $84.51 \%$ of the variations on capital flight between the entities (countries of the EAC) are explained by the explanatory variables in the model. The overall R squared is 0.5434 . This means that $54.34 \%$ of the changes on the dependent variable (capital flight) in EAC are explained by the explanatory variables that are included in the model. From the results of $\mathrm{R}$ squared above, the model of the study was a good fit since all the R squared results attained $50 \%$ and above.

Hausman (1978) test was conducted to select the preferred model between the fixed effect and random effect model. The results showed that the fixed effect model was appropriate for the study while Pesaran's (2011) test for cross sectional dependence showed that there was no cross sectional dependence. Wooldridge (2006) test for autocorrelation was used to establish whether the error terms of different time periods are correlated or not and the results of the test showed they are not correlated. Heteroscedasticity test was carried out to establish whether the error terms exhibit constant variance across observations or not. Modified Wald test for group wise heteroscedasticity was employed and results showed no heteroscedasticity.

\section{Conclusion and Recommendations}

\subsection{Conclusion}

The fixed effect regression results showed that external debt and exchange rate had a positive and statistically significant effect on capital flight while real GDP had a negative and statistically significant effect on capital flight. However, interest rate differential was found to have a positive but statistically insignificant effect on capital flight. This therefore showed that EAC regions have to work hard in implementing both monetary and fiscal policies that 
will reduce capital flight.

The negative and statistically significant relationship between real GDP and capital flight could be because deterioration in the performance of the economy increases the proportion of private wealth portfolio held abroad. The positive and statistically significant effect of external debt on capital flight could be because most of the external borrowings in EAC are transformed instantaneously from capital inflow to capital flight, ultimately ending up abroad, usually in a private foreign account. As a result, with increased failure in repaying back debt or when there is a high potential of default, it will lead to capital outflows from developing countries associated with nonrepayment risks. The positive and statistically significant interactive effect of corruption index on capital flight implies that under situations of poor governance and bad institutional quality, corrupt public authorities take advantage to hoard personal wealth overseas thus leading to low tax and capital accumulation to improve the wellbeing of citizens and even to increase investment in the domestic developing countries.

\subsection{Recommendations}

There is need to put into place transparency mechanisms by regularly providing information to the populations with respect to the management and use of both borrowed and domestically finance developments within the EAC member States. The governments of EAC States need to pursue policies that are geared towards reducing the debt stock in order to reduce this effect on capital flight. Through the Central Bank of the EAC member states, monetary policies should be adopted where foreign exchanges are kept at a point that allows for the country's currency to be exchanged at realistic prices. The governments of EAC States should also consider ensuring that there is increased public sector investments in areas perceived essential to economic growth.

\subsection{Areas of Future Research}

The third objective (external debt) was considered with no intention to include domestic debt effect on capital flight, so domestic debt effect studies on capital flight are recommended in future studies so as to assess how both domestic and external debt influence capital flight in short and long run.

\section{References}

Al-fayoumi, N. A., Alzoubi, M. S., \& Bank, C. (2012). The Determinants Of Capital Flight: Evidence From MENA Countries, $11(1), 1-10$.

Babu, J., Kiprop, S., Kalio, A., \& Gisore, N. (2014). External debt and economic growth in East Africa. African Journal of Business Management, 8(21), 1011-1018.

Bigsten, A., \& Kayizzi-Mugerwa, S. (1999). Is Uganda an emerging economy? A report for the OECD project \&quot; Emerging Africa \&quot; , (May).

Buckley, P. J. (2016). Historical Research Approaches to the Analysis of Internationalisation. Management International Review, 56(6), 879-900.

Centre for Applied Research, N. S. of E., Global Financial Integrity, University, J. N., Socioeconômicos, I. de E., \& Research, N. I. of S. and E. (2015). Financial Flows and Tax Havens Combining to Limit the Lives of Billions of People, (December), 113.

Dunning, J.H., \& Robson, P. (Eds.) (1988). Multinationals and the European Community. Oxford: Basil Blackwell.

Forson, R., Obeng, K. C., \& Brafu-Insaidoo, W. (2017). Determinants of Capital Flight in Ghana. Journal of Development Studies, 22(4), 1124-1156.

Gisore, M. (2021). Determinants of regional economic growth in Kenya. African Journal of Business Management, $15(1), 1-12$

Hausman, J. (1978) Specification Tests in Econometrics. Econometrica, No. 46, 1251-1271. International Corporate Service Organization. (2013). Tanzania, 2014(2005), 1-10.

International Monetary Fund (2011). Enhancing Development Assistance to Africa: Lessons from Scaling-up Scenarios (Washington: International Monetary Fund).

Kar, D., \& Cartwright-Smith, D. (2010). Illicit financial flows from Africa: Hidden resource for development. Global Financial Integrity, 44.

Kenya National Bureau of Statistics-KNBS (2017), Economic Survey. Nairobi: Government Printer.

Kolapo, F. T., \& Oke, M. O. (2000). Nigerian Economic Growth and Capital Flight Determinants. Asian Journal of Business and Management Sciences, 1(11), 2047-252876.

Levin, A., Lin, C., and Chu, C. (2002). Unit Root Tests in Panel Data: Asymptotic and Finite-Sample Properties. Journal of Econometrics, No. 108, 1-24.

Liew, S.-L. (2016). Review of Determinants of Capital Flight, (70445).

Makochekanwa, A. (2007). An Empirical Investigation of Capital Flight from Zimbabwe.

Markowitz, H. (1952). Portfolio Selection. The Journal of Finance, 7(1), 77-91.

McClure, B. (2010). Modern portfolio theory: Why it's still hip. Retrieved on 12/11/2018 from ftp://ftp.repec.org/opt/ReDIF/RePEc/ibf/gjbres/gjbr-v7n1-2013/GJBR-V7N1-2013-6.pdf (May-23-2019). 
Ndikumana, L., \& Boyce, J. K. (2012). Capital flight from North African countries PERI Research Report. Amherst, MA: Political Economy Research Institute.

Ndikumana, L., \& Boyce, J K. (2011). Capital flight from Sub-Saharan African countries: linkages with external borrowing and policy options. International Review of Applied Economics, 25(2), 149-170.

Ndikumana, L., \& Sarr, M. (2016). WIDER Working Paper 2016 / 58 Capital flight and foreign direct investment in Africa An investigation of the role of natural resource endowment, (May).

Ndoricimpa, A. (2018). Greed of the elite; capital flight from a fragile country: Case of Burundi. Journal of Financial Crime.

Ng'eno, N.K. (2000). Capital Flight in Kenya in Ibi Ajayi and Mohsin Khan (Eds.) External Debt and Capital Flight in Sub-Saharan Africa. Washington, D.C.: The World Bank, 300-321.

Nyoni, T. (2000). Capital Flight from Tanzania in Ajayi, Ibi and Mohsin Khan (Eds.) External Debt and Capital Flight in Sub-Saharan Africa. Washington, D.C.: The IMF Institute, 265-299.

Osei-Assibey, E., Domfeh, K. O., \& Danquah, M. (2018). Corruption, institutions and capital flight: evidence from Sub-Saharan Africa. Journal of Economic Studies.

Pedroni, P. (1999). Crucial Values for Cointegration Tests in Heterogenous Panels with Multiple Regressors. Oxford Bulletin of Economics and Statistics, No. 61, 653-670.

Pesaran, M. H. (2011). On the Interpretation of Panel Unit Rot Tests. Jounal of Econometrics, 1.

Schneider, B. (2003). Working Paper 194 Measuring Capital Flight :, (March).

World Bank Group. (2018). World development indicators 2018. World Bank Publications.

World Bank Group. (2008). World development indicators 2010. World Bank Publications.

World Bank Group. (2016). Global Development Finance (2016), CDROM edition.

World Bank Annual General Meeting. (2005). A Perspective on the Doha Development Agenda: Aid for Trade, Enhanced National Revenues and Debt Sustainability. Washington D.C.: World Bank, Sept. 22. Roundtable: Civil Society Policy Dialogue Program.

World Bank. (2017). The State of Kenya's Economy, (December 2017 Edition No.9), 16-31. 